\title{
The Relationship of Deposits with Profit Rates and Advances with Mark-up Rates in Pakistan
}

\author{
DR. SAID SHAH \\ Assistant Professor and Head, Department of Management Sciences \\ University of Swabi, Pakistan \\ saidshah64@yahoo.com \\ SAFDAR HUSAIN TAHIR \\ Assistant Professor and Head, Department of Banking \& Finance \\ Government College University, Faisalabad, Pakistan \\ safdartahir@gmail.com
}

\begin{abstract}
This article is regarding banking industry of Pakistan. The paper examines the extent to which deposits and advances are dependent on profit and mark up rates respectively. The required data on all the public sector banks and two private banks for six years (19992004) were obtained and analyzed using regression analysis. The results show that the relationship is quite strong in case of saving and current deposits. It has further been concluded on the basis of this analysis that there is a strong Correlation between advances and mark up rates.
\end{abstract}

Keywords: Advances, deposits, mark up rate, profit rate, Pakistan

\section{Introduction}

A bank for economy is like heart for a human body and plays a vital role in economic development of a nation. The banking industry has become more complex by introducing new products in the fields of advances, deposits, international trade etc. since early 1990s as against past when the banking job simply to accept deposits and give loans. In present banking too, advances and deposits play a very key role in increasing the efficiency of a bank. The more efficient a bank will be, the more confidence the general public will be having in it. The size of these two more important components on a bank's balance sheet is dependent on various factors besides mark up and profit rates. Apart from mark up and profit rates, professionalism of the management, efficiency of the staff, consistency in government policies and world political conditions also affect the size of advances and deposits. In order to ensure the soundness of financial and operational condition of the banking industry, protect the interest of depositors and ensure achievement of the projected profitability, all the factors effecting the volume of deposits and advances must be minutely examined and analyzed.

A number of factors affect the volume of deposits and advances in different ways based on each individual's interest. Such as a bank's management is interested to charge maximum mark up on advances and allow a minimum profit on deposits in order to 
widen the spread towards earning profits. Both of these factors (mark up and profit rates) affect the dependent variables (volume of advances and deposits) in the same direction. As in case of law of demand, increase in price of a commodity leads towards reduction in its demand. Just like this, with an increase in mark up rates, the demand for loans is reduced and ultimately its volume also reduced.. Likewise, with a reduction in profit rates, the demand for deposits (on depositors' side) is reduced and ultimately its volume also reduced.

There are several features relating to the creation of deposits by the South African commercial banks in the post world war II period which appear to hold out special significance for the conduct and efficacy of monetary policy in South Africa. These features are (a) the ease with which the public generally is able to acquire means of payment in the form of commercial bank deposits (b) the impact of external trade and foreign capital on the balance of payments (c), the impact of interest rate policy on the demand for commercial bank deposits (or bank credit) in the South African economy in the post-war period (d) to face any emergency needs arising out of an extraordinary events such as war etc., (e) the continuous shift which has taken place from interest-free demand deposits to interest-bearing time deposits (Cloete, 2006).

\subsection{Objectives of The Study}

The main objective of this article is to determine whether the volume of advances and deposits are only dependent upon mark up and profit rates respectively or there are also other factors which contribute in this regard.

\section{Literature Review}

Concentration in a specific sector say dependence only on consumer lending due to bankers strict or conservative policies towards advances and their eagerness for increasing their profitability only through rising interest rates on advances inversely leads to reducing their profitability and weakening their financial performance. Mere following conservative policies with highest mark up rates is not in favour of banks and they should bring their policies in accordance with the behavior of the public. In a study on determining the impact of market conditions on bank deposit interest rates and examining data for 1988-2000, Rosen (2007) found that rates are affected by market size structure. The study also found large differences between urban and rural markets and that in rural areas, changes in market concentration have no effect on deposit rates. Stronger competition implies significantly lower spreads between bank and market interest rates for most loan market products, in line with expectations. This result implies that stronger competition causes both lower bank interest rates and a stronger passthrough of market rate changes into bank rates (Leuvensteijn \& Bikker, 2008).

Fraser (2005), in his study analyzed a sample of 78 banks and concluded that the principal distinction between high and low profit banks is the expenses which are to be reduced rather than the revenue which is earned. According to LIM (2001), it is worth speculating on the implication of banking practices which are strictly consumer oriented and one sided, that is if banks only pass on decreases to loan rates. Strict adherence to such a consumer-oriented policy will lead to a squeeze on profits and hence greater pressure to adopt risky, imprudent lending strategies leading to greater risk of financial 
instability. The results reported here are based on a simultaneous approach which takes into account the profit motive. Extraordinary high rates on deposits as well as extraordinary low rates on advances also negatively influence the investment policies of various regions or sectors within the country and in the world as well. Offering highest rates on deposits may be affordable for a few banks but a cause of disaster for others. So the policy of determining profit rates on deposits and mark up rates on advances must be realistic and not based on artificial tactics, window dressing and other policies like that.

Eichengreen and Mody (1998) found that qualitative accounts have long emphasized the state of global financial markets, as proxied by interest rates in the advanced industrial countries, as a determinant of capital flows to emerging markets and the pricing of external debt. Curiously, econometric studies relying on disaggregated data have lent little support to this emphasis. Higher US rates have a negative impact on demand for international investors for fixed-rate issues by Latin American borrowers, as predicted by the search-for-yield hypothesis. The same effect is apparent for East Asian floating -rate issues, although the evidence in such cases is not robust. But this effect is evident only upon controlling for the impact of US interest rates on the decision of developing-country borrowers to issue debt. Higher interest rates in the major money centers have a negative impact on the borrower's issue decision. This effect is strongest for East Asian Issues of fixed-rate securities, who appear to have been best able to withhold new placements when US interest rates rise curtailing the supply of emergingmarket paper and putting upward pressure on bond prices-effectively limiting the rise in spreads. Amount deposited is a source of creating loans which ultimately result in decline of market liquidity (Gatev \& Strahan, 2006).

\section{Methodology and Data}

Annual reports for six years from all the public sector banks and also from two private commercial banks have been used as a source of data. Primary data has also been collected through meetings with concerned people. The variables which have been used for this study are as under:

\subsection{Variables}

In case of advances, independent variable is mark up rate on advances and dependent variable is volume of advances. In case of deposits, independent variable is profit rate on deposits and dependent variable is volume of deposits.

\subsection{Model}

The following model has been used for the calculation of the extent to which volume of advances is dependent upon mark up rates:

$$
\text { Vadvi }=\mathbf{a}+\mathbf{b}(\mathbf{m u})+u i
$$

Where Vadvi shows volume of advances in period $\mathrm{i}$, mu indicates mark up rate, a is constant, $\mathrm{b}$ is coefficient and $u$ is error term.

In order to further determine the relationship between deposits and profit rates the following regression equation has been used:

$$
\mathrm{Vdep} i=\mathrm{a}+\mathrm{b}(\mathrm{pr})+u i
$$

Where Vdepi shows volume of deposits in period i, pr indicates profit rate, a is constant, 
$\mathrm{b}$ is coefficient and $u$ is error term.

\subsection{Justification of Model}

The above model is most suited to measure the relationship between advances and deposits and mark up rates and profit rates respectively as such this model has been used.

\subsection{Analysis}

This research covers the entire public sector and partially private sector. In this research article, I have analyzed the data obtained from five commercial banks (three in the public sector and two in the private sector). The following are the banks:

\subsection{Public Sector}

- The Bank of Khyber

- The Bank of Punjab

- National Bank of Pakistan

\subsection{Private Sector}

- Askari Commercial bank

- Prime Commercial Bank

\subsection{Statistical Tools used}

The key statistical tools used are Coefficient of Correlation to determine the relationship between the profit rates and volume of deposits and Coefficient of Determination to measure the impact of change in dependent variable, volume of deposits and advances due to change in independent variable, profit and mark up rates.

\section{Results and Findings}

The data has been analyzed to determine whether the deposits and advances are fully dependent on profit rates and mark up rates respectively or there are also other variables which affect the same. In determining the relationship between advances and mark up rates, independent variable is mark up rate on advances and dependent variable is volume of advances. In determining the relationship between deposits and profit rates, independent variable is profit rates on deposits and dependent variable is volume of deposits.

Table 1: The Impact of Profit Rates on Volume of Deposits 1999-2004 (Rs. In million)

\begin{tabular}{|lccccccccc|}
\hline Bank & \multicolumn{3}{c}{ Fixed Deposits } & \multicolumn{3}{c|}{ Saving Deposits } & \multicolumn{3}{c|}{ Current Deposits } \\
\hline & $\begin{array}{c}\text { Coefficient } \\
\text { of } \\
\text { Correlation }\end{array}$ & $\begin{array}{l}\text { Coefficient of } \\
\text { Determination }\end{array}$ & sig & $\begin{array}{l}\text { Coefficient } \\
\text { of } \\
\text { Correlation }\end{array}$ & $\begin{array}{l}\text { Coefficient of } \\
\text { Determination }\end{array}$ & sig & $\begin{array}{c}\text { Coefficient of } \\
\text { Correlation }\end{array}$ & $\begin{array}{c}\text { Coefficient of } \\
\text { Determination }\end{array}$ & Sig \\
\hline B.O.K & 0.33153 & 0.10991 & 0.520 & 0.946889 & 0.896599 & 0.004 & 0.930725 & 0.86625 & 0.007 \\
B.O.P. & 0.96000 & 0.92161 & 0.002 & 0.914229 & 0.835814 & 0.010 & 0.754866 & 0.569823 & 0.082 \\
N.B.P. & 0.47889 & 0.22933 & 0.336 & 0.976636 & 0.953818 & 0.000 & 0.957746 & 0.917278 & 0.002 \\
A.C.B & 0.78223 & 0.61188 & 0.065 & 0.930548 & 0.86592 & 0.007 & 0.822625 & 0.676712 & 0.044 \\
P.C.B. & 0.97200 & 0.94478 & 0.001 & 0.969715 & 0.940348 & 0.001 & 0.804939 & 0.647926 & 0.053 \\
& & & & & & & & & \\
\hline
\end{tabular}

Results show that the relationship is quite strong and is significant at $10 \%$ level in case of saving and current deposits. However in case of fixed deposits, there is a weak 
positive relationship in The Bank of Khyber and National Bank of Pakistan which is statistically insignificant. It means there are other factors also which effect volumes of fixed deposits. Coefficient of Determination measures the impact of change in dependent variable due to change in independent variable. Results show that the dependent variable i.e. deposits are strongly dependent upon the independent variable i.e. profit rates in case of saving and current deposits. However in case of fixed deposits, the independent variable explains a low change due to change in dependent variable for The Bank of Khyber and National Bank of Pakistan.

Bank of Khyber

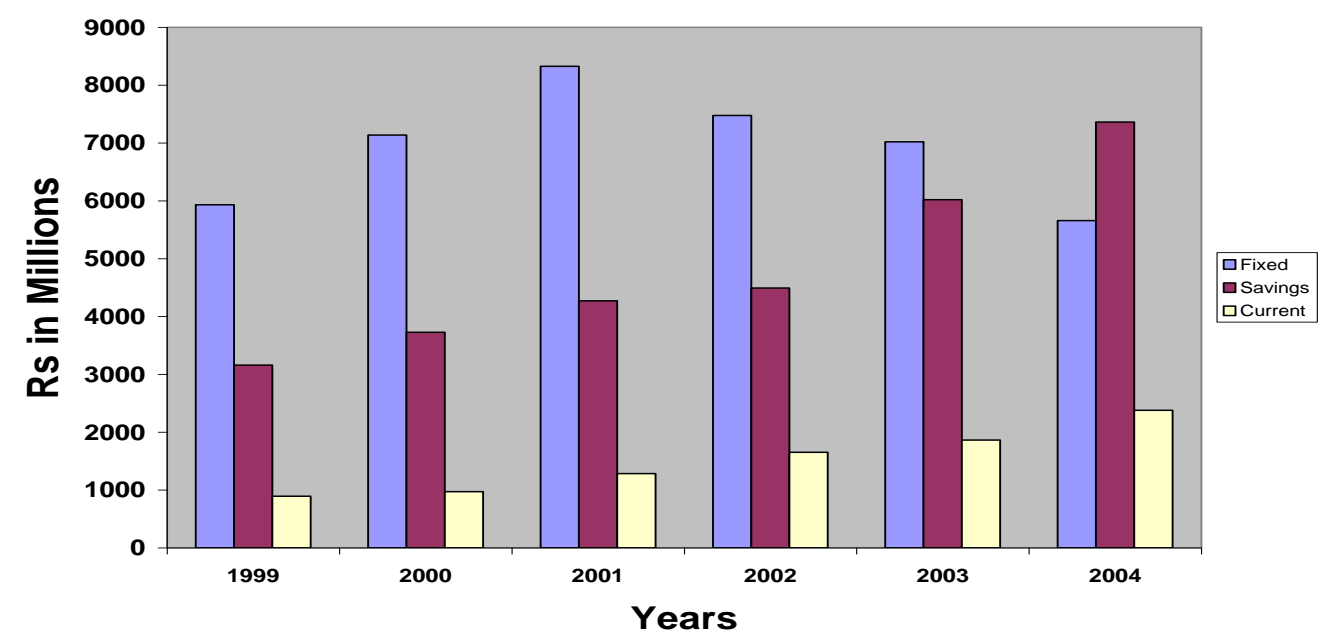

Figure 1: Diagrammatical presentation of volume of deposits (The Bank of Khyber)

The Bank of Punjab

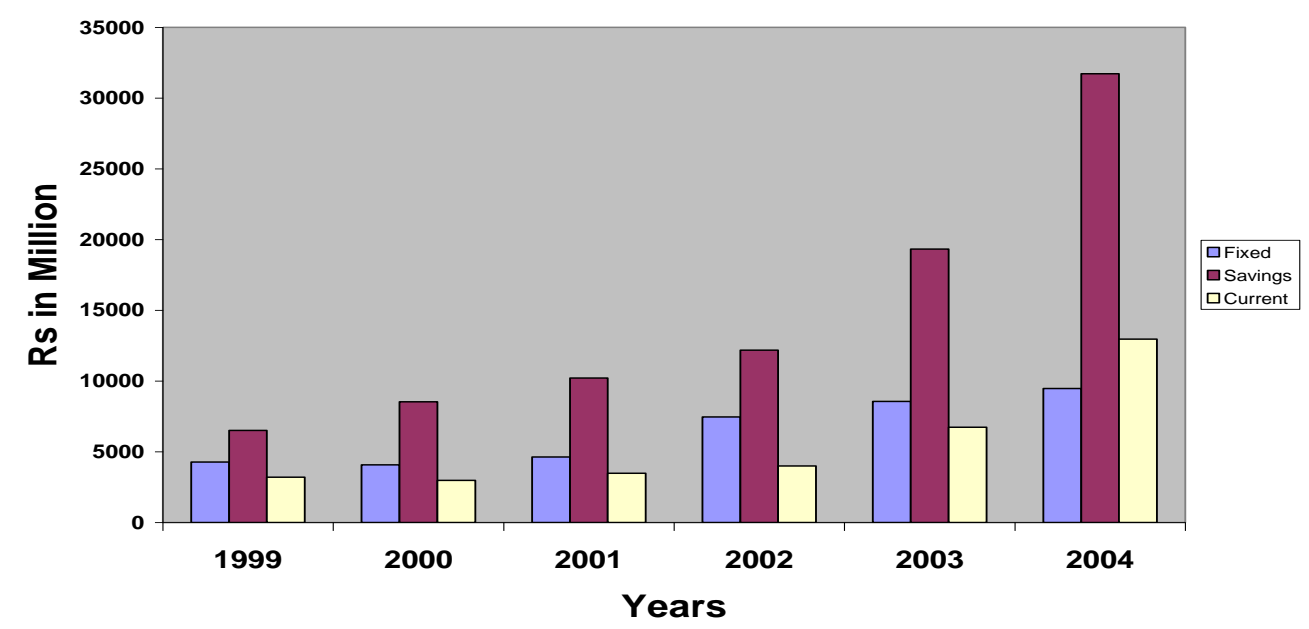


Figure 2: Diagrammatical presentation of volume of deposits (The Bank of Punjab)

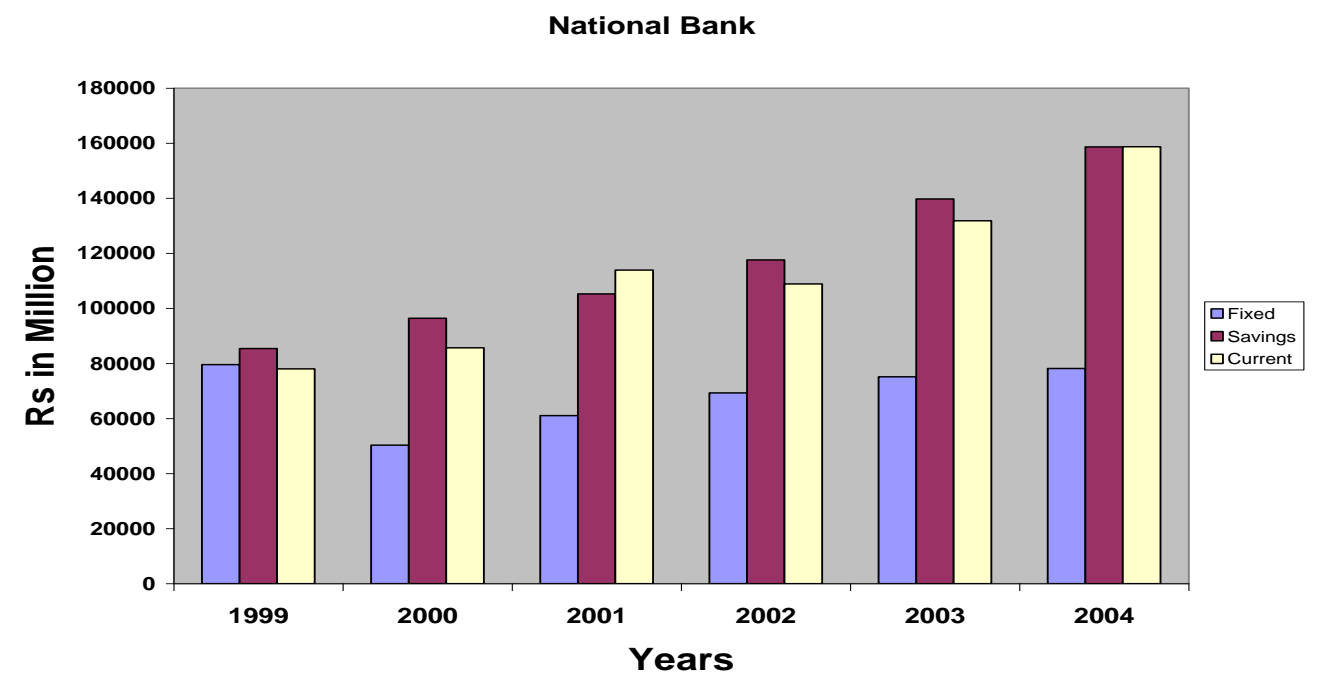

Figure 3: Diagrammatical presentation of volume of deposits (National Bank of Pakistan)

\section{Askari Bank}

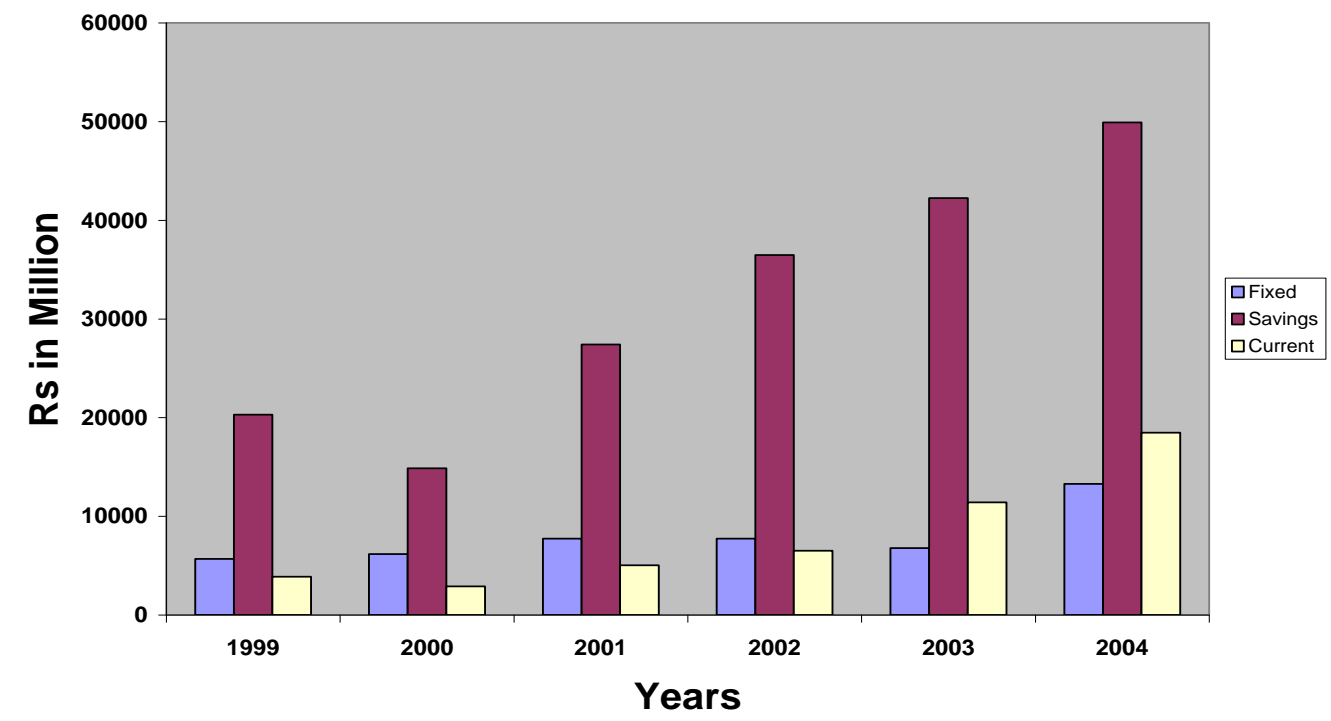


Figure 4: Diagrammatical presentation of volume of deposits (Askari Commercial Bank)

\section{Prime Bank}

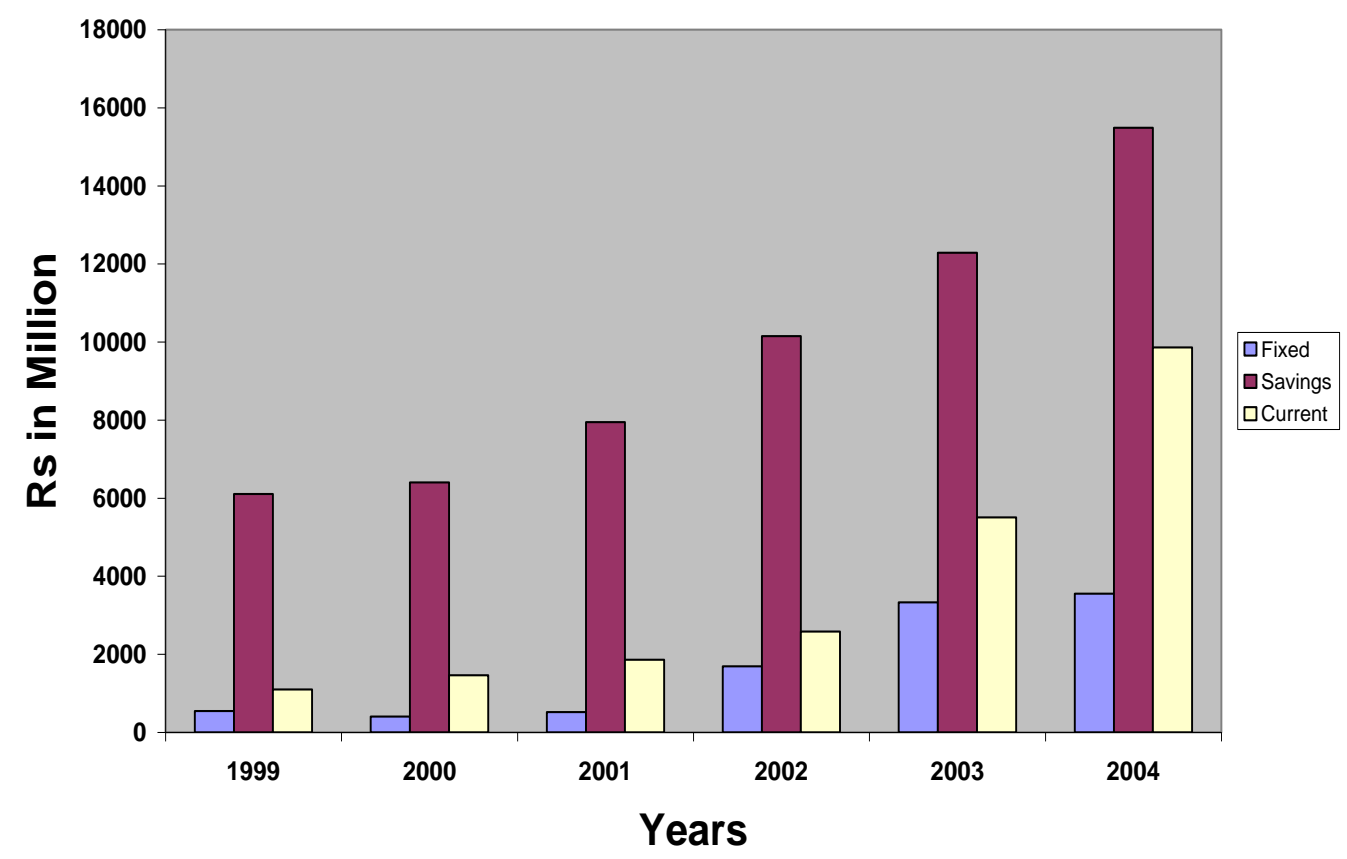

Figure 5: Diagrammatical presentation of volume of deposits (Prime Commercial Bank)

Table 2: The Impact of Mark up Rates on Volume of Advances: 1999-2004 (Rs. In million)

\begin{tabular}{llll}
\hline Name of Bank & \multicolumn{2}{c}{ Advances } \\
\hline & Coefficient of Correlation & Coefficient of Determination & P-Value \\
\hline The Bank of Khyber & 0.406864 & 0.165538 & 0.42338 \\
The Bank of Punjab & 0.861946 & 0.74295 & 0.027273 \\
National Bank & 0.745536 & & 0.088889 \\
Askari Bank & 0.91023 & 0.555824 & 0.011726 \\
Prime Commercial Bank & 0.90922 & 0.828519 & 0.011988
\end{tabular}


There is strong Correlation between advances and mark up rates for all the banks except for Bank of Khyber. Co efficient of determination show that independent variable i.e. mark up rate explains significant portion of their dependent variable i.e. advances at 10 percent level, with the exception of bank of Khyber where the results show that there exists very weak relationship and based on p- value it is statistically insignificant.

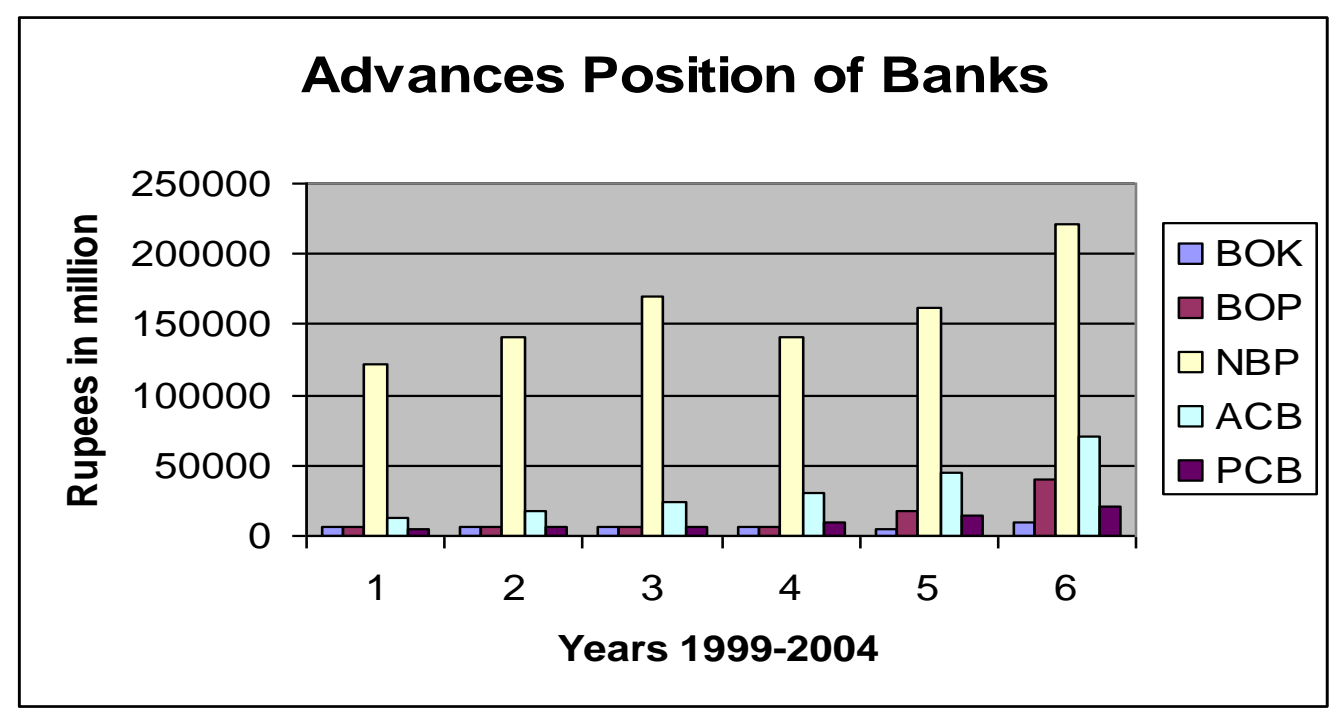

Figure 6: Diagrammatical presentation of volume of advances for all the sample banks

\section{Conclusion}

The results show that the relationship is quite strong in case of saving and current deposits. However in case of fixed deposits, there is a weak but positive relationship. It means there are other factors also which effect volumes of fixed deposits. The dependent variable i.e. deposits are strongly dependent upon the independent variable i.e. profit rates in case of saving and current deposits. However in case of fixed deposits, the independent variable explains a low change due to change in dependent variable. Furthermore, results of the majority of the banks in the data show that there is a strong Correlation between advances and mark up rates and co efficient of determination indicates that independent variable i.e. mark up rate explains significant portion of their dependent variable.

\section{References}

Cloete (2006). The Implications for Monetary Policy of Post-War Developments in the Market for Bank Deposits, South African Journal of Economics, 38 (3) 192-203. DOI: 10.1111/j.1813-6982.1970.tb00260.x

Eichengreen \& Mody (1998). Interest Rates in North and Capital Flows to South: Is There a Missing Link, International Finance, 1(1), 35-57 
Fraser, (2005). The Determinants of Bank Profits: An Analysis of Extremes, The Financial review 003/2005; 11(1):69-87. DOI:10.1111/j.15406288.1976.tb00938.x

Gatev \& Strahan (2006). Bank's Advantage in Hedging Liquidity Risk: Theory and Evidence from the Commercial Paper market, The journal of Finance, 61 (2) 867-892, DOI: 10.1111/j.1540-6261.2006.00857.x

Leuvensteijn \& Bikker (2008). Impact of bank competition on the interest rate passthrough in the euro area, European Central Bank, Working Paper Series, No. 885

LIM (2001). Bank Rates Adjustments: Are They Asymmetric, The Economic Record, 77 (237), 135-147

Richard, J. R. (2007). Banking market conditions and deposit interest rates, Journal of Banking and Finance, 31(12) 3862-3884. DOI:10.1016/j.jbankfin. State Bank of Pakistan's Prudential Regulations

\section{List of Abbreviations}

Appendix

BOK: Bank of Khyber,

BOP: Bank of Punjab

NBP: National bank of Pakistan

ACB: Askari Commercial Bank

PCB: Prime Commercial bank 